\title{
ECHO-11 as a Respiratory Virus: Quantitation of Infection in Man
}

\author{
Gilbert S. Saliba, Sylvia L. Franklin, and George Gee Jackson \\ From the Research and Educational Hospitals, Department of Medicine, University of \\ Illinois College of Medicine, Chicago, Illinois 60680
}

A B S T R A C T Through a series of controlled experiments in volunteers, quantitative aspects of infection, illness, and immunity to ECHO-11 virus were studied. ECHO-11 is a transmissable viral infection in man and equally infectious to the upper respiratory and the intestinal tracts. The rate of infection was directly related to the dose of virus exposure, but any infectious dose of virus produced illness in only about one-third of the infected subjects. The infectious dose for man varied over a billionfold range. Larger challenge doses caused no difference in the local symptoms at the portal of entry or in the peak severity of illness, but symptoms were more diverse and prolonged after a higher dose. Persons with asymptomatic infections became just as heavily infected as ill persons.

In respiratory secretions from natural infection, the titer of infectious virus was found to be about $10^{2}$ median infective doses in tissue culture $\left(\operatorname{TCID}_{50}\right) / \mathrm{ml}$. At this level, up to $40 \%$ of exposed contacts could be infected per milliliter of secretion. The observed rate of spread was $24 \%$. This lowdose inoculum caused illness in $12 \%$ of volunteers

The research for this study was reviewed and approved by the institutional committee of associates and performed with the signed, informed consent of each volunteer. An abstract of the preliminary results appeared in Proceedings of the Central Society for Clinical Research. 1966. J. Lab. Clin. Med. 68: 1010.

Dr. Saliba is a trainee in infectious diseases. Dr. Franklin is a research associate in Medicine. Dr. Jackson is a professor of medicine. Address requests for reprints to Dr. George Gee Jackson, Professor of Medicine, University of Illinois Medical Center, P. O. Box 6998, Chicago, Ill. 60680.

Received for publication 11 October 1967 and in revised form 17 January 1968. but failed to elicit a significant antibody response in $93 \%$ or immunity to reinfection and another illness upon rechallenge. Larger doses of virus produced a longer excretion of virus and a significant increase in serum-neutralizing antibody. $\mathrm{Na}$ sal antibody was infrequently found. The principal effect of antibody was to decrease virus excretion and to shorten illness; it reduced the rate but did not prevent infection. Attempts to produce an asymptomatic enteric infection which would induce immunity failed.

The characteristics of respiratory transmission with mild disease, recurent infection, and illness without a detectable antibody response or solid immunity to reinfection, satisfy the epidemiologic conditions to establish ECHO-11 virus as one of the causes of the common cold.

\section{INTRODUCTION}

With the development of tissue culture techniques, many viruses were recovered from the enteric tract of healthy individuals $(1,2)$. Their relation to human illness was unknown, and they failed to produce disease in common laboratory animals. In 1955, this group of viruses was designated enteric cytopathogenic, human orphan or $\mathrm{ECHO}$ viruses (3).

The prototype ECHO-11 virus was isolated in 1954 from a rectal specimen of a healthy child (1). Subsequently, infection with ECHO-11 virus has been found in cases of aseptic meningitis, (4-6), exanthem (7), acute gastroenteritis $(8,9)$, and acute respiratory disease $(10,11)$. In studies of acute respiratory disease in a day nursery in Sweden, Philipson isolated seven strains of the 
U (Uppsala) virus from cases of nondiphtheritic croup. This agent was later shown to be antigenically related to the ECHO-11 prototype virus (12). The U virus was successfully transmitted to human volunteers in two series of studies performed by Philipson in Uppsala, Sweden and by Buckland, Bynoe, Philipson, and Tyrrell in Salisbury, England (13, 14).

The present investigations were initiated because of the recovery of ECHO-11 virus from the nasal secretions of adults with common colds. In a series of controlled experiments in volunteers, quantitative aspects of infection, illness, and immunity were studied. The results establish the capability of ECHO-11 virus as an etiologic agent of respiratory illness and showed that the virus had the properties of transmissability, infectivity, virulence, and antigenicity characteristic of the epidemiology of common colds.

\section{METHODS}

ECHO-11 virus was recovered on either primary rhesus monkey kidney or diploid human embryo fibroblast (WI-38) tissue cultures from the nasal secretions of three adults with naturaly acquired, typical common colds. These secretions were collected voluntarily as part of a surveillance program for acute respiratory diseases. The nasal secretions from two subjects (NS 243 and NS 248) were diluted 1:5 with Earle's balanced salt solution (EBSS), homogenized, passed through a Millipore filter, and stored at $-70^{\circ} \mathrm{C}$. The isolated viruses were propagated through ten passages in African green monkey kidney cell cultures in serum-free medium. The harvests of virus from the 10th tissue culture passage (NS 243

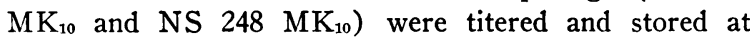

$-70^{\circ} \mathrm{C}$. A portion of the harvest of NS $243 \mathrm{MK}_{10}$ was diluted 1:2 with nonfat milk, lyophilized, mixed with lactose, and distributed into double-thickness gelatin capsules for oral administration. The titer of virus in the capsule was determined on a suspension of the powder from one capsule in $1.0 \mathrm{ml}$ of EBSS. The various challenge materials and their infectivity titers in rhesus monkey kidney cells are given in Table I. For convenience in description, the nasal secretion and the dilute tissue culture harvest given as nose drops and the lyophilized harvest given orally were considered a low-dosage challenge; the high-titer tissue culture harvest was considered a high-dose challenge. All materials administered to volunteers were safety-tested to exclude the presence of other detectable microorganisms (15).

127 volunteers were selected from the student and employee population of the University of Illinois College of Medicine and affiliated institutions. All were young adults in good general health who denied symptoms of acute respiratory disease during the preceding 2 wk. The studies were of $10 \mathrm{wk}$ duration, during which the volunteers continued their usual daily activities but reported to the Infectious Diseases Unit at appointed times for the recording of symptoms, the receiving of challenge materials, and the collection of specimens. Challenge materials were administered at the beginning of the 1st and 7th wk of study, according to the schedule shown in Table II. At the beginning of the 1st wk, all volunteers were given $0.4 \mathrm{ml}$ of challenge material as nose drops and also ingested a gelatin capsule. At the beginning of the 7th wk, volunteers were given only the $0.4 \mathrm{ml}$ intranasal challenge. Oral temperatures were taken and recorded on the day of challenge and on days 1,2 , 4, 7, and 10 after challenge. An impartial observer interviewed each volunteer on the above days. Eight symptoms of acute respiratory disease: headache, sneezing, chilliness, nasal discharge, nasal obstruction, sore throat, cough, malaise, were recorded as to their presence and severity on each day. The criteria for identifying the development of a cold in a volunteer and the reasons for

TABLE I

Challenge Materials

\begin{tabular}{llccc}
\hline Source & Dilution & Volume & Route & Dose TcrD 50* \\
\hline $\begin{array}{l}\text { Low dosage } \\
\text { Nasal secretion }\end{array}$ & $1: 5$ & $0.4 \mathrm{ml}$ & Nose drops & $10^{2}$ \\
$\quad \begin{array}{l}\text { Tissue culture }(\mathrm{MK}) \\
\quad \text { Passage 10 }\end{array}$ & $1: 1000$ & $0.4 \mathrm{ml}$ & Nose drops & $10^{3}$ \\
$\quad \begin{array}{c}\text { Tissue culture }(\mathrm{MK}) \\
\quad \text { Passage 10 }\end{array}$ & $1: 2$ & $\begin{array}{c}\text { (Lyophilized) } \\
1.0 \mathrm{ml}\end{array}$ & Oral capsule & $10^{4}$ \\
$\begin{array}{l}\text { High dosage } \\
\quad \text { Tissue culture }(\mathrm{MK}) \\
\quad \text { Passage 10 }\end{array}$ & $1: 5$ & & & \\
\end{tabular}

MK, monkey kidney; $I_{50}$, median infective dose.

* ECHO-11 virus titer in monkey kidney tissue culture. 
TABLE II

Challenge Sichedule

\begin{tabular}{|c|c|c|c|c|c|c|c|}
\hline \multicolumn{5}{|c|}{ Challenge } & \multicolumn{3}{|c|}{ Rechallenge ( $6 \mathrm{wk}$ ) } \\
\hline \multirow[b]{2}{*}{$\begin{array}{l}\text { No. of } \\
\text { volunteers }\end{array}$} & \multicolumn{2}{|c|}{ Nose dirops } & \multicolumn{2}{|c|}{ Oral capsule } & \multirow[b]{2}{*}{$\begin{array}{l}\text { No. of } \\
\text { volunteers }\end{array}$} & \multicolumn{2}{|c|}{ Nose drops } \\
\hline & Material & $\begin{array}{l}\text { Virus* } \\
\text { dose }\end{array}$ & Material & $\begin{array}{l}\text { lirus } \\
\text { dose }\end{array}$ & & Material & $\begin{array}{l}\text { Virus } \\
\text { dose }\end{array}$ \\
\hline 39 & IS 24.3 & $10^{2}$ & Lactose & () & 38 & & \\
\hline 11 & $\mathrm{MKTC}_{10}$ & $10^{:}$ & Lactose & () & 9 & & \\
\hline 10 & $11 \mathrm{KTC}$ & $10^{\mathrm{E}}$ & Lactose & 0 & 10 & $\mathrm{ILTC}_{10}$ & $10^{6}$ \\
\hline 20 & Saline & 0 & Dried $\mathrm{MKTC}_{10}$ & $10^{4}$ & 15 & & \\
\hline 10 & Saline & 0 & Lactose & 0 & 10 & & \\
\hline \multirow[t]{3}{*}{5} & Saline & 0 & Iactose & 0 & 5 & Saline & 0 \\
\hline & \multirow{2}{*}{\multicolumn{4}{|c|}{$\begin{array}{l}\text { Nonparticipants } \\
\text { Nonparticipants }\end{array}$}} & 6 & Saline & 0 \\
\hline & & & & & 12 & $\mathrm{MK}^{\prime} \mathrm{TC}_{10}$ & $10^{6}$ \\
\hline
\end{tabular}

$\mathrm{NS}$, nasal secretions; MKTC, monkey kidney tissue culture.

* ECHO-11 virus titer in monkey tissue culture.

their adoption have been given in detail in another publication (16).

Nasal washings were collected before each challenge and on days 1, 2, 4, 7, and 10 postchallenge for virus isolation studies. $8 \mathrm{ml}$ of Earle's balanced salt solution were introduced into the nares with the head hyperextended; the head was rotated for $10 \mathrm{sec}$ and the fluid drained into a sterile petri dish. Rectal swabs were collected on days 4,7 , and 10 postchallenge, the fecal material was dispersed in $5 \mathrm{ml}$ of Solution 199 with $2 \%$ serum albumin and antibiotics, centrifuged at $3500 \mathrm{rpm}$ for $20 \mathrm{~min}$, and the supernate used for virus isolation. Blood and urine specimens for virus isolation were collected from 12 volunteers on days $0-4$.

Within $6 \mathrm{hr}$ after collection, $0.2 \mathrm{ml}$ of all specimens were inoculated into each of three tubes containing a monolayer of rhesus monkey kidney cells and $0.9 \mathrm{ml}$ of Solution 199 with antibiotics. Each set of tubes was observed for cytopathic effect through at least two tissue culture passages of 10-14 days each. Positive harvests were identified by neutralization with specific antisera.

Blood specimens for serologic studies were collected on days $0,14,42,56$, and 70 . The serum titer of neutralizing antibody against $10-100 \mathrm{TCID}_{50}$ of the homologous strain of ECHO-11 virus was letermined for all sera by the microtiter technique with rhesus monkey kidney cells in secondary culture. The antibody titer was determined as the highest twofold dilution of serum that prevented or nearly prevented $(1+)$ cytopathic effect $(\mathrm{CPE})$ when the infectivity control showed complete $(3-4+)$ CPE. This was usually after 4 days of incubation. An increase of fourfold or more was considered a significant antibody rise.

\section{RESULTS}

Infectivity of ECHO-11 virus in ioluntecrs. Volunteers were challenged with doses of
ECHO-11 virus varying from $10^{2}$ to $10^{6}$ infectious doses for $50 \%$ of green monkey kidney tissue culture tubes $\left(\mathrm{TCID}_{\overline{5} 0}\right)$. The virus was given by either the nasal or oral route. Infection was determined by recovery of the challenge virus from the nasal washings and (or) rectal swabs collected during the 10 days after the challenge. As shown in Fig. 1, infectivity was directly related to the dose of virus given and approached a linear function of the logarithm of the dose. This permitted estimation of the dose-related slope of infectivity of ECHO-11 virus for man, the observed median infective dose, $\left(\mathrm{HuID}_{\tilde{z} 0}\right)$, and calculation of the theoretical minimal infectious dose. By either the

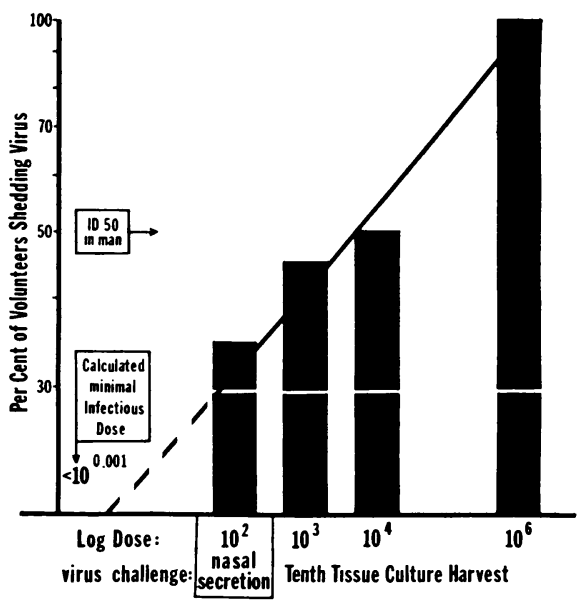

FIGIRE 1 Infectivity of ECHO-11 virus in volunteers. ID, infective dose. 
respiratory or enteric route, the $\mathrm{HuID}_{50}$ was 10,000 monkey kidney TCID $_{50}$. After a high-dose intranasal challenge $\left(\begin{array}{lll}10^{6} & \mathrm{TCID}_{50}\end{array}\right)$ all subjects became infected. By extrapolation, the minimal infectious dose for man was less than $1 / 1000$ $\mathrm{TCID}_{50}$. In the nasal secretion of donors with a naturally acquired ECHO-11 virus infection, the titer of virus was $10^{2}$ TCID $_{50}$. Nasal discharges during infection, therefore, contained about 100,000 minimal infectious doses of virus for man per milliliter. The transmission of infection by natural means was demonstrated in 4 of 24 volunteers (16\%) who were given a placebo challenge (saline). Their exposure to one or more of the experimentally infected volunteers was casual and intermittent over a 10 day period.

If the virus was introduced into the respiratory tract, the greater focus of infection was there. As noted in Table III, after a low-dose nasal challenge $\left(10^{2}-10^{3}\right)$, the percentage of volunteers shedding virus from the nose was approximately three times as great as the number shedding rectal virus. Introduction of virus into the enteric tract by oral capsule resulted in equal infection of the gastrointestinal and respiratory tracts. The route of infection of the respiratory tract is unknown. A1though double-thickness gelatin capsules were used, the virus was not enteric-coated and may have become suspended in the gastric contents and regurgitated. Viremia was not demonstrated in 12 subjects from whom blood and urine were collected on days 1-4 postchallenge and inoculated directly onto tissue culture. All volunteers given high titer virus by the nasal route shed virus from both the respiratory and enteric tracts.

Common colds relative to the dose of virus challenge. Challenge with ECHO-11 virus characteristically induced a mild, afebrile upper respira-

TABLE III

Shedding of ECHO-11 Virus Relative to the Portal of Entry

\begin{tabular}{|c|c|c|c|c|c|c|}
\hline \multirow{2}{*}{\multicolumn{3}{|c|}{ Challenge }} & \multicolumn{4}{|c|}{ Virus recovery } \\
\hline & & & \multicolumn{2}{|c|}{ Nose } & \multicolumn{2}{|c|}{ Rectum } \\
\hline Route & Dose & $\begin{array}{c}\text { No. of } \\
\text { Volunteers }\end{array}$ & No. & $\%$ & No. & $\%$ \\
\hline Nasal & Low & 45 & 17 & 38 & 6 & 13 \\
\hline Oral & Low & 20 & 6 & 30 & 6 & 30 \\
\hline Nasal & High & 32 & 32 & 100 & 32 & 100 \\
\hline
\end{tabular}

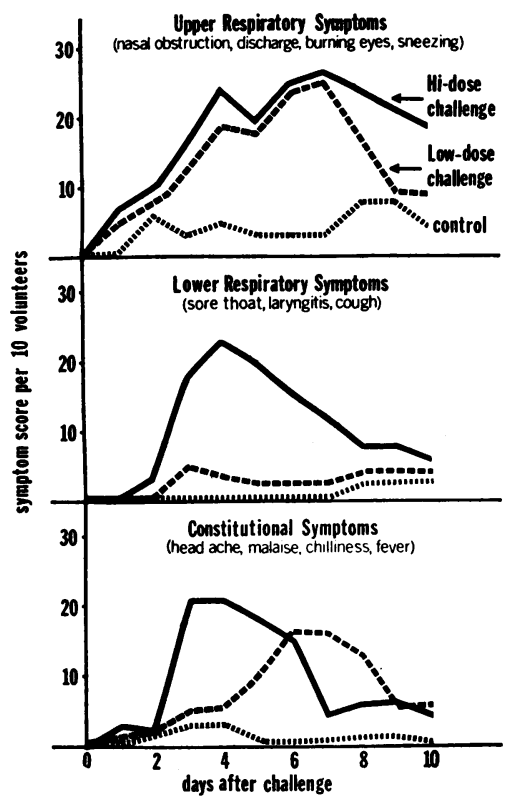

Figure 2 Syndrome of ECHO-11 virus respiratory infection in adults : effect of the challenge dose.

tory illness with constitutional symptoms (Fig. 2). The incubation period after challenge was short, 24-48 hr. The earliest symptoms were nasal obstruction, postnasal discharge, and headache. After $48 \mathrm{hr}$, rhinorrhea began and was accompanied by pharyngitis and lower respiratory symptoms if they were going to occur, and by the abrupt development of malaise with chilliness. These symptoms rapidly reached their peak severity on the 3rd or 4 th day after the challenge. By the 5th day, there was beginning remission of all symptoms. For the lower respiratory and constitutional symptoms, the remission was progressive with decline near-normal after $1 \mathrm{wk}$. For the upper respiratory symptoms, the improvement about the 5th day was brief and followed immediately by an exacerbation of the local nasal complaints which rose to a new peak of severity on the 7 th day, before a gradual and progressive decline in symptoms occurred. There were no gastrointestinal symptoms that could be related to the enteric infections. A few people had occasional loose stools, but the same was found among uninfected controls. 4 of 36 infected, ill persons had an oral temperature elevation above $99^{\circ} \mathrm{F}$; in two of them, $(1.6 \%$ of all infected persons) temperature was 101 and $102^{\circ} \mathrm{F}$.

Whether the infection was initiated with a large or small challenge dose of virus made no differ-

1306 G. S. Saliba, S. L. Franklin, and G. G. Jackson 
ence to the symptoms at the portal of infection, i.e. upper respiratory symptoms, except for the rate of recovery (Fig. 2). It had considerable effect on lower respiratory and constitutional symptoms. If the infecting dose was small, there were few or no symptoms of lower respiratory infection. Also, the constitutional symptoms had a later and lower peak which occurred at the time of maximal nasal symptoms. A large-challenge inoculum caused earlier constitutional symptoms and pharyngitis, laryngitis, and cough which were almost entirely absent when the inoculum was small.

In Fig. 3, the two parallel lines show the relation of the incidences of infection and of illness. As shown by the ratios in the center boxes, only one-third of infected persons became ill, and the illness-to-infection ratio was essentially constant regardless of the dose of virus. Therefore, virulence (the ability of the microbe to overcome host defenses against illness) was not affected by dose, although the proportion of persons infected was. Volunteers given the original nasal secretion had almost the same illness-to-infection ratio as those given the 10th tissue culture passage of virus. This almost constant ratio indicates that no demonstrable attenuation of the virus occurred as a result of 10 passages in monkey kidney tissue cultures.

The relation of the severity of respiratory illness to the dose of ECHO-11 virus given in the challenge is shown in Fig. 4. The mean symptom score for the group of ill volunteers on the day of most severe illness is illustrated by the bars. The

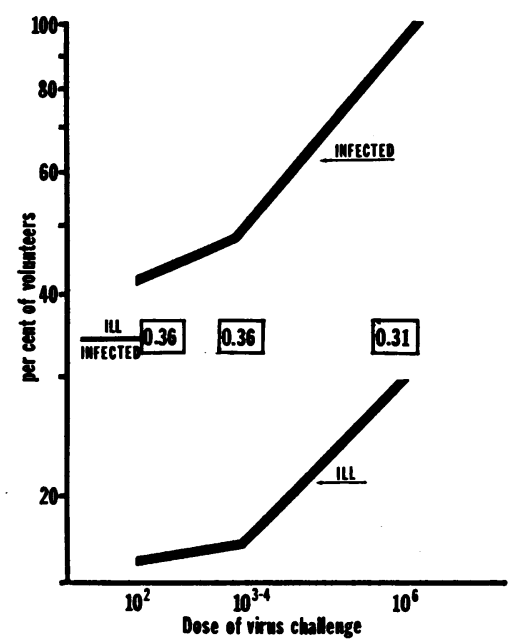

Figure 3 Frequency of common colds relative to the dose of ECHO-11 virus.

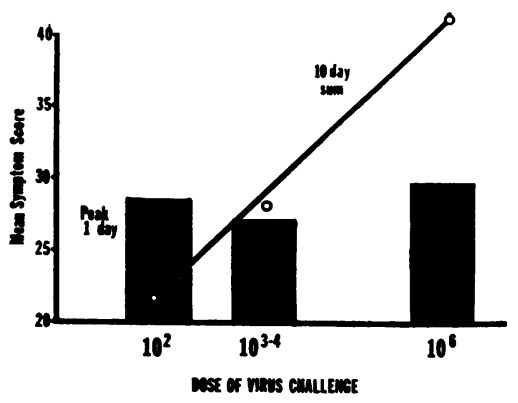

FIGURE 4 Severity of respiratory illness relative to the dose of ECHO-11 virus. The bars show the 1 day of worst illness. The circles connected by the line show the mean total symptom score for the 10 day period after each of the three levels of virus challenge.

scores are of comparable height (severity) for the three challenge groups given different doses of virus. The circles connected by the line show the mean total symptom score for the 10 day period after each of three levels of virus challenge. There was a direct linear increase in the sum of symptoms for 10 days which was proportional to the dose of virus given. A large amount of virus in the challenge dose, therefore, affected the time and duration of symptoms without altering the peak severity of the disease.

Virus shedding and serologic response to infection. The low-dose challenge given by either the respiratory or oral route produced infection in 30 of 70 volunteers (Table IV). Among 24 who had respiratory tract infection, 8 were ill, but because the virus excretion pattern was the same, ill and nonill volunteers are tabulated together. About one-fourth of the nasal washings and one-eighth of the rectal specimens collected during the 10 days after challenge contained virus. 10 of the 31 nasal isolates were made 1 day after the challenge, but virus shedding was found in some members of the group, both ill and nonill, on every day of sampling. All of these isolates are interpreted as infection with in vivo replication of virus. A rise in serum antibody occurred in only two subjects who had multiple isolates without illness. Among the group with enteric infection only, the mode day of most virus excretion was 10 days after challenge, and usually there was more than one positive specimen. None of six subjects had a measurable antibody rise. 40 persons had neither virus shedding nor antibody rises and are designated as nonin- 
TABLE IV

Virus Shedding and Serologic Response to Challenge with ECHO-11 Virus

\begin{tabular}{|c|c|c|c|c|c|c|c|c|}
\hline & \multirow{3}{*}{$\begin{array}{c}\text { No. of } \\
\text { volunteers }\end{array}$} & \multirow[b]{3}{*}{$\%$} & \multicolumn{4}{|c|}{ Virus recovery } & \multirow{2}{*}{\multicolumn{2}{|c|}{$\begin{array}{l}\text { Antibody } \\
\text { rise }(4 \times)\end{array}$}} \\
\hline & & & \multicolumn{2}{|c|}{ Nasal specimens } & \multicolumn{2}{|c|}{ Rectal specimens } & & \\
\hline & & & Positive/total & $\%$ & Positive/total & $\%$ & No. & $\%$ \\
\hline \multicolumn{9}{|l|}{ Low dose } \\
\hline Respiratory infection* & 24 & 34 & $31 / 119$ & 26 & $9 / 72$ & 12 & 2 & 8 \\
\hline Enteric infection only & 6 & 9 & $0 / 30$ & - & $9 / 18$ & 50 & 0 & - \\
\hline Noninfected & 40 & 57 & $0 / 200$ & - & $0 / 120$ & - & 0 & - \\
\hline \multicolumn{9}{|l|}{ High dose } \\
\hline Respiratory and enteric infection & 32 & 100 & $106 / 160$ & 66 & $71 / 96$ & 74 & 30 & 94 \\
\hline
\end{tabular}

* With or without enteric infection.

fected. The amount of virus in the low-dose challenge, therefore, was infectious for $43 \%$ of subjects and caused illness in $12 \%$ but elicited a serologic rise in only $7 \%$ of those infected and in none of the eight with respiratory illness. The high challenge dose of virus infected everyone and produced virus shedding in two-thirds of nasal and three-fourths of rectal specimens. A rise in serum antibody occurred in $94 \%$ of the subjects. Thus, the serologic response to infection was related to the amount of virus that initiated the infection or the resulting longer duration of virus shedding. It related poorly to whether or not the infected person was ill.

Effect of antibody. Among 98 volunteers tested for antibody against ECHO-11 virus before challenge, 33 had a titer of $1: 10$; in 15 of them it was $1: 20$ or greater. The effect of prechallenge serumneutralizing antibody on the prevention or limitation of infection is shown in Table V. A serum titer of $1: 10$ had no demonstrable effect and is tabulated with the no antibody group. 10 persons who were rechallenged after they developed antibody induced by experimental rechallenge with the same virus also are noted.

When a low challenge dose of virus was given, an antibody titer of $1: 20$ or more reduced by onethird the percentage of infected volunteers; the percentage of specimens containing virus was reduced about one-half. Serum antibody did not reduce the proportion of volunteers with illness, but the 10 day mean symptom score for the group with antibody was lower. If a high-dose challenge was given, the only effect of preexisting natural antibody at a titer of $1: 20$ or more was a reduction in the percentage of specimens yielding virus. If the antibody was induced by a recent direct nasopharyngeal challenge with the same virus, there was a further suppression of virus shedding and also a decrease in infection and illness. Thus, the prime effect of serum-neutralizing antibody was to curtail the extent of virus shedding; if the challenge dose was small, the number of persons infected and the duration of symptoms were decreased. Serum antibody had its least effect in reducing the percentage of persons who became ill.

Tests for neutralizing antibody in the nasal washings were made in 10 subjects who received successive challenges with a high dose of virus. The protein content of the concentrated washings was $2.5-3.0 \mathrm{mg} / \mathrm{ml}$ (about $1 / 25$ that of serum). Antibody was found in one person before challenge and three after the first but before the second challenge. When present, nasal antibody reduced the frequency of virus isolation from nasal washings by $40 \%$ from the results in comparable subjects without nasal antibody. However, a previous challenge with a high dose of virus had a greater effect, even when no nasal antibody was demonstrated.

Immunity to rechallenge. To test the immunizing effect of prior respiratory and intestinal infection, volunteers from each of the challenge groups were rechallenged with the high dose of virus 6 wk after the original challenge. The results are given in Table VI according to the different doses of ECHO-11 virus. The frequency of illness is shown and the level of infection indicated by the proportion of nasal and rectal specimens containing virus during the 10 days after exposure and 
TABLE V

Effect of Prechallenge Serum Neutralizing Antibody on Infection and Illness

\begin{tabular}{|c|c|c|c|c|c|}
\hline \multirow[b]{3}{*}{$\begin{array}{c}\text { Antibody* } \\
\text { titer }\end{array}$} & \multirow[b]{3}{*}{$\begin{array}{c}\text { No. of } \\
\text { volunteers }\end{array}$} & \multirow{2}{*}{\multicolumn{2}{|c|}{ Infected }} & \multicolumn{2}{|c|}{ III } \\
\hline & & & & & Group \\
\hline & & $\begin{array}{c}\% \text { of } \\
\text { volunteers }\end{array}$ & $\begin{array}{c}\% \text { of } \\
\text { specimens }\end{array}$ & $\begin{array}{c}\% \text { of } \\
\text { volunteers }\end{array}$ & $\begin{array}{l}\text { symptom } \\
\text { score }\end{array}$ \\
\hline \multicolumn{6}{|l|}{ Low-dose challenge } \\
\hline 10 or less & 63 & 43 & 22 & 12 & 11.5 \\
\hline 20 or more & 7 & 29 & 12 & 14 & 7.4 \\
\hline \multicolumn{6}{|l|}{ High-dose challenge } \\
\hline 10 or less & 83 & 100 & 72 & 29 & 13.8 \\
\hline 20 or more, natural & 8 & 100 & 44 & 36 & 15.2 \\
\hline 20 or more, induced & 10 & 72 & 15 & 9 & 8.8 \\
\hline
\end{tabular}

Reciprocal of highest dilution of serum that neutralized $10-30$ TCID $_{50}$ of ECHO-11 virus.

by the frequency of fourfold increases in serum antibody.

An initial high-dose challenge infected all subjects and produced illness in 10 or $31 \%$. After a prior initial low-dose challenge, all subjected also were infected and one-half of those previously given a high-dose challenge. The group that had infection of the respiratory tract and then became reinfected were unusually susceptible to illness from infection. Initially 8 of 24 were ill. Upon rechallenge, 10 of $21(48 \%)$ became ill, whereas in the cohort group, which was not infected by the first low-dose challenge, only 8 of $38(21 \%)$ became ill. The difference is appreciable but not statistically significant. A partial explanation may be in the number of people who had prechallenge serum antibody, which was present in $20 \%$ of the latter and only $7 \%$ of the former. Among the total group previously given a low dose of virus, 18 of 54 persons $(33 \%)$ became ill on rechallenge com-

TABLE VI

Effect of Prior Challenge upon Infection after Rechallenge ECHO-11 Virus (High Dose)

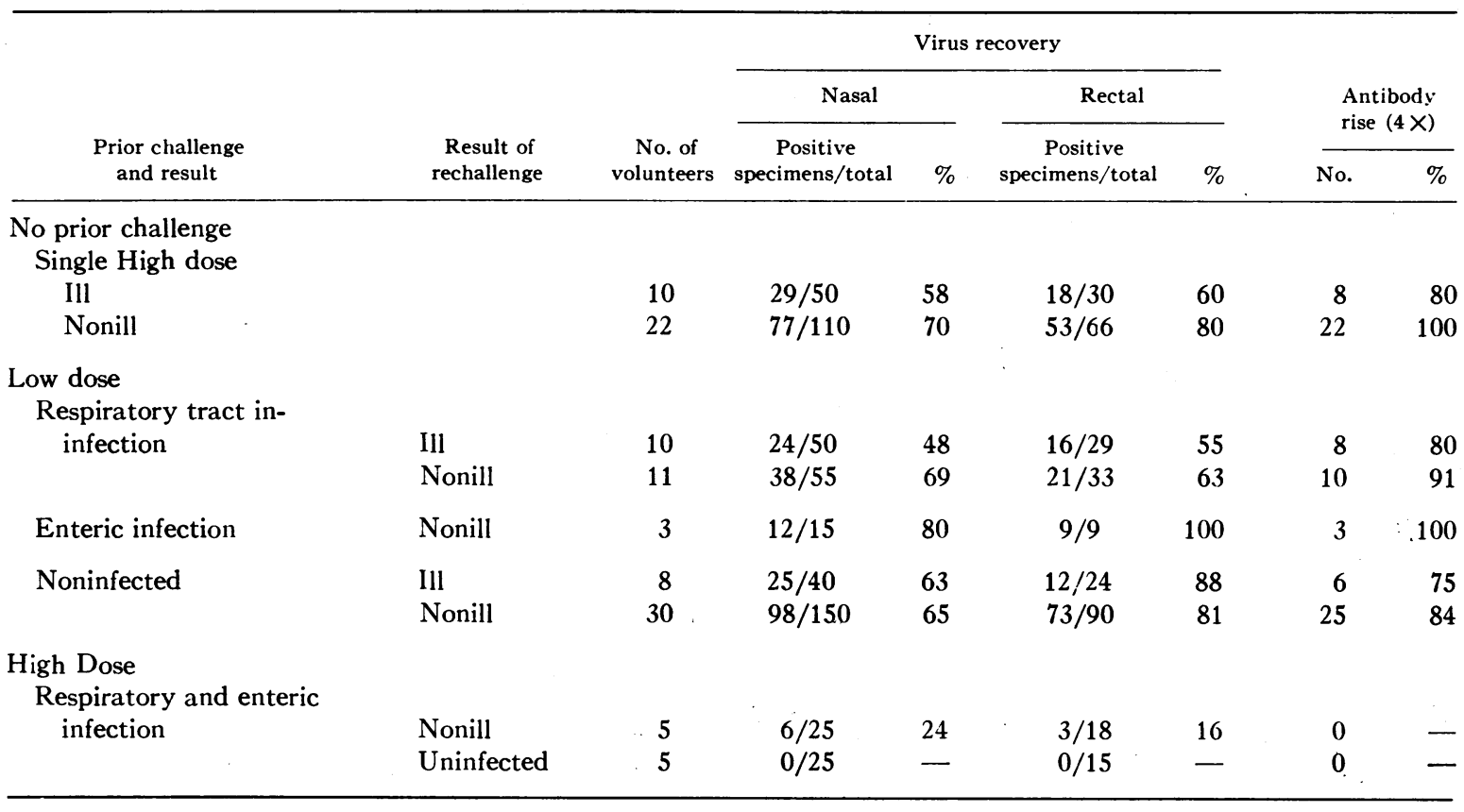


pared to $31 \%$ in the control group. Therefore, no immunity to illness was produced by the low-dose challenge.

Those persons who became ill did not shed more virus (virus in more specimens) than volunteers who were infected but not ill. In fact, the trend is consistently the opposite. Thus, persons with inapparent infections were not just lightly infected. Comparison of virus recovery data from persons after initial challenge and from persons rechallenged after an earlier respiratory tract infection induced by the low dose of virus shows no significant difference and hence no evidence for increased resistance against reinfection. A trend toward excretion of less virus in rectal specimens is discounted by the observation that all of the nine specimens from three persons who had enteric infection with the initial challenge contained virus after rechallenge. Among persons with prior infection from a high-dose initial challenge, no illness occurred after rechallenge, infection was decreased, and the amount of virus shedding by those who became infected was markedly reduced. Therefore, prior infection with a low dose of virus, whether symptomatic or asymptomatic, was not protective against reinfection or illness, whereas prior infection with a high dose of virus induced an antibody response prevented illness and reduced infection from rechallenge.

Prior infection, even with a low dose of virus, however, had some ameliorating effect on the symptoms of the second infection. In Fig. 5, it can be seen that when the mean daily symptom score for each group is plotted, prior challenge with a low dose of virus reduced the mean severity of symptoms and shortened the duration of illness. Prior

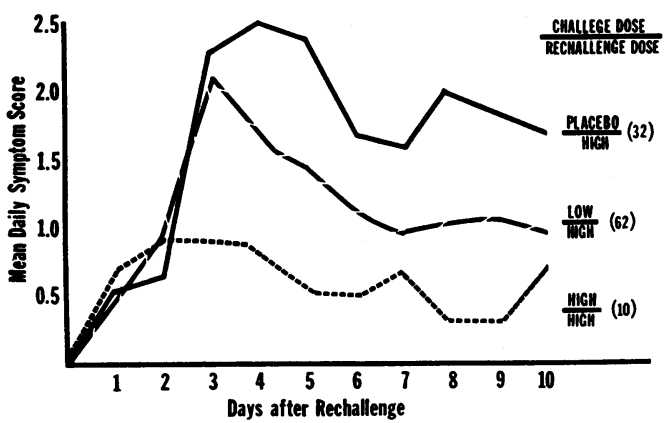

FIgURE 5 Mean daily symptom score after rechallenge. The numbers of persons comprising each group is shown in parentheses. infection initiated by a high dose of virus completely eliminated the symptoms of infection relative to the placebo group.

\section{DISCUSSION}

ECHO viruses and rhinoviruses are closely related agents. Both belong to the group of picornaviruses; they have RNA-type nucleic acid, are small $(30-50 \mathrm{~m} \mu)$, and are insensitive to ether. The two classes of viruses are similar in nearly all biological properties, except that rhinoviruses are acid labile. Although rhinoviruses are the principal cause of common colds in adults $(17,18)$, they do not infect the gastrointestinal tract, presumably because they fail to pass the acidity of the stomach in a viable state. ECHO viruses are prevalent in the intestine as asymptomatic infections, but they have been isolated relatively infrequently from adults and children with acute respiratory illnesses $(11,19)$.

Rhinoviruses have been successfully transmitted to volunteers and acute respiratory illness readily induced (20-23). In surveillance studies, some $\mathrm{ECHO}$ viruses have been implicated as etiologic agents of acute respiratory illness (13). Also, controlled investigations in volunteers challenged with ECHO-11 or ECHO-20 virus have demonstrated the capacity of these agents to produce respiratory illness $(14,24)$. The investigations reported here were done to further explore the potential of ECHO-11 virus as a cause of respiratory tract infection. By controlling the virus dose, time, and route of administration, it was possible to elucidate the characteristics of infection. The use of ECHO11 virus from adults with naturally acquired colds permitted demonstration of the low virulence of the virus but the lack of further attenuation after several tissue culture passages. The high titer of virus harvested from tissue cultures made it possible to achieve infection of all volunteers and thereby study the quantitative relationships of the challenge dose to infection, illness, serologic response, and immunity. The acid stability of the ECHO-11 virus offered the chance to study whether selective asymptomatic bowel infection, if it could be accomplished, would induce immunity against infection of the respiratory tract as a means of live virus vaccination against picornaviruses as has been done with Adenovirus type 4 (25). 
Among the factors pertaining to respiratory infections with $\mathrm{ECHO}$ viruses is the question of the susceptibility of the respiratory epithelium relative to the bowel. The observation that oral capsules which released virus into the stomach or intestine caused as much infection of the respiratory tract as of the bowel suggests that the respiratory tract is equally or more susceptible. The infrequency of isolation of ECHO-11 virus from persons with respiratory illness is, therefore, probably a reflection of the larger proportion of inapparent infections compared to infections with rhinoviruses.

The infection rate of volunteers was directly related to the concentration of virus administered. An infectious dose for man was estimated to be from $1 / 1000$ to $10^{6} \mathrm{TCID}_{50}$, covering a range of one billionfold in the amount of virus. Because nasal secretions in naturally acquired infections contained only about $100 \mathrm{TCID}_{50}$ and 1000 were required to infect $50 \%$ of persons, the circumstances explain why ECHO-11 virus has not been observed to be a highly epidemic respiratory infection in the general population; it has been epidemic in a few small groups of susceptible children $(6,8-10)$. Estimates for influenza virus, Adenovirus type 4 , and rubella virus, all of which cause epidemic respiratory disease, suggest that a smaller amount of virus is required for a $50 \%$ infectious dose than that observed for ECHO-11 virus. The implication is that the slope of virus infectivity in relation to the amount of virus shed in the respiratory secretions is one determinant in whether or not a virus causes epidemic respiratory disease. With ECHO-11 virus, only about one-sixth of contacts became infected, which is the number expected from exposure to $0.1 \mathrm{ml}$ of nasal secretion. Among those who were infected experimentally, less than one-third were ill. This degree of contagion and disease is compatible with clinical experience with the common cold and also explains why the observed role of ECHO-11 virus is a minor one among the multiple viral causes of the common cold.

Although the rate of infection of volunteers was a direct function of the dose of virus, the number of infected persons who became ill was relatively independent of the challenge dose. The time of most complaints and the character of the syndrome were the features of infection most affected by the dose of virus. In earlier experience with
Reovirus type 1 , only volunteers in whom the infection was initiated with a high concentration of virus $\left(10^{5-6} \mathrm{TCID}_{50}\right)$ experienced clinical illness (26). The analogy with these results appears to be that only a high dose of virus caused enough diverse symptoms which were sufficiently protracted to be recognized as illness. If this is a general principle, it seems worthy of emphasis. The size of the infecting dose of a respiratory virus exhibits itself more by variation in the symptomatology and duration of illness than by the acute severity of the disease. This makes clinical recognition of the specific etiology of nonepidemic respiratory illness impossible.

In several of the clinical disease states that have been etiologically related by isolation of ECHO-11 virus, serologic response could not be demonstrated $(8,13)$. A similar experience has been described in cases of acute respiratory disease with rhinovirus infections (27-29). Our observations establish that under experimental conditions, infection and illness resulting from ECHO-11 virus can ocur without a demonstrated serologic response. Also, these persons were susceptible to reinfection and illness with the same virus. This explains another troublesome aspect of the common cold.

The development of neutralizing-serum antibody was related to the amount of challenge virus and (or) the extent and duration of virus shedding and not to the presence or absence of illness. The amount of virus acquired from $1.0 \mathrm{ml}$ of nasal secretion $\left(10^{2}\right)$ elicited a significant increase in serum antibody in only $7 \%$ of infected persons. The use of serology for determining the incidence or documenting the specific etiology of ECHO-11 virus infections would considerably underestimate its frequency. In the serologic surveillance, 30\% of young adults had some detectable antibody. Thus, natural infection must be prevalent. It is conceivable that a similar dose-response relation exists with other ECHO and rhinovirus infections and provides one explanation for the observed infrequent serologic responses to virus-associated rhinitis.

If present, both serum- and nasal-neutralizing antibody decreased infection. Especially, they curtailed virus shedding and shortened illness, but neither infection nor illness was prevented. The failure of serum-neutralizing antibody to prevent 
illness has been most notable with myxovirus infections (30). The absence of antibody in nasal secretions which is of different origin and immunoglobulin type than that in serum has been of importance (31-33). Another explanation for the lack of protection provided by serum antibody is antigenic variation among strains of viruses (34). In the studies reported here, two serologic variants of ECHO-11 were used without any demonstrable clinical difference.

Because the method of initiating enteric infection also resulted in frequent infection of the respiratory tract, it was not possible to test whether immunity against respiratory illness could be produced by selective local asymptomatic bowel infection. At present, the method appears to be an unlikely one for effective immunization against respiratory infection with picornaviruses.

\section{ACKNOWLEDGMENTS}

This work was conducted under the sponsorship of the Commission on Acute Respiratory Diseases of the Armed Forces Epidemiological Board. The studies were supported in part by a grant from the U. S. Public Health Service, E 4059, a training grant from the U. S. Public Health Service, AI 208, and in part by the Medical Research and Development Command, Department of the Army, under Research Contract No. DA-193-MD-2410.

\section{REFERENCES}

1. Ramos-Alvarez, M., and A. B. Sabin. 1954. Characteristics of poliomyelitis and other enteric viruses recovered in tissue culture from healthy American children. Proc. Soc. Exptl. Biol. Med. 87: 655.

2. Ormsbee, R. A., and J. L. Melnick. 1957. Biologic and serologic characteristics of ECHO viruses from West Virginia. J. Immunol. 79: 384.

3. Committee on ECHO Viruses. 1955. Enteric cytopathogenic human orphan (ECHO) viruses. National Foundation of Infantile Paralysis. Science. 122: 1187.

4. Elvin-Lewis, M., and J. L. Melnick. 1959. ECHO 11 virus associated with aseptic meningitis. Proc. Soc. Exptl. Biol. Med. 102: 647.

5. Von Zeipel, G., M. Ohlson, O. Kahlmeter, and A. Svedmyr. 1960. Isolation of ECHO 11 virus from the cerebrospinal fluid of cases of aseptic meningitis. Acta Pathol. Microbiol. Scand. 49: 249.

6. Froeschle, J. E., P. M. Feorino, and H. M. Gelfand. 1966. A continuing surveillance of enterovirus infection in healthy children in six United States cities. II. Surveillance enterovirus isolates 1960-1963 and comparison with enterovirus isolates from cases of acute central nervous system disease. Am. J. Epidemiol. 83: 455.
7. Cherry, J. D., A. M. Lerner, J. O. Klein, and M. Finland. 1963. ECHO 11 virus infections associated with exanthems. Pediatrics. 32: 509.

8. Klein, J. O., A. M. Lerner, and M. Finland. 1960. Acute gastroenteritis associated with $\mathrm{ECHO}$ virus, type 11. Am. J. Med. Sci. 240: 749.

9. Bergamini, F., and F. Bonetti. 1960. Épisodio epidemico di gastroenterite acuta da virus ECHO-11 in un Brefotrofio. Boll. Ist. Sieroterap. Milan. 39: 510.

10. Philipson, L. 1958. Association between a recently isolated virus and an epidemic of upper respiratory disease in a day nursery. Arch. Ges. Virusforsch. 8: 204.

11. Elveback, L. R., J. P. Fox, A. Ketler, C. D. Brandt, F. E. Wasserman, and C. E. Hall. 1966. The Virus Watch program: a continuing surveillance of viral infections in metropolitan New York families. III. Preliminary report on association of infections with discase. Am. J. Epidemiol. 83: 436.

12. Philipson, L., and L. Rosen. 1959. Identification of a cytopathogenic agent called U-virus recovered from patients with nondiphtheritic croup and from daynursery children. Arch. Ges. Virusforsch. 9: 25.

13. Philipson, L. 1958. Experiments in human adults with a recently isolated virus associated with respiratory disease. Arch. Ges. Virusforsch. 8: 318.

14. Buckland, F. E., M. L. Bynoe, L. Philipson, and D. A. J. Tyrrell. 1959. Experimental infection of human volunteers with the U-virus-a strain of ECHO virus type 11. J. Hyg. 57: 274.

15. Knight, V. 1964. The use of volunteers in medical virology. In Progress in Medical Virology. S. Karger, AG., Basel. 6. 1.

16. Jackson, G. G., H. F. Dowling, I. G. Spiesman, and A. V. Boand. 1958. Transmission of the common cold to volunteers under controlled conditions. I. The common cold as a clinical entity. Arch. Internal Med. $101: 267$.

17. Hamre, D., A. P. Connelly, Jr., and J. J. Procknow. 1966. Virologic studies of acute respiratory disease in young adults. IV. Virus isolation during four years of surveillance. Am. J. Epidemiol. 83: 238.

18. Gwaltney, J. M., J. O. Hendley, G. Simon, and W. S. Jordan, Jr. 1966. Rhinovirus infections in an industrial population. I. The occurrence of illness. New Engl. J. Med. 275: 1261.

19. Johnson, K. M., H. H. Bloom, B. Forsyth, M. A. Mufson, P. A. Webb, and R. M. Chanock. 1963. The role of enteroviruses in respiratory disease. Am. Rev. Respirat. Diseases. 88: 240.

20. Jackson, G. G., H. F. Dowling, and W. J. Mogabgab. 1960. Infectivity and interrelationships of 2060 and JH viruses in volunteers. J. Lab. Clin. Med. 55: 331.

21. Bynoe, M. L., D. Hobson, J. Horner, A. Kipps, G. C. Schild, and D. A. Tyrrell. 1961. Inoculation of human volunteers with a strain of virus isolated from a common cold. Lancet. 1: 1194.

22. Mufson, M. A., W. M. Ludwig, H. D. James, Jr., L. W. Gauld, J. A. Rourke, J. C. Holper, and R. M. 
Chanock. 1963. Effect of neutralizing antibody on experimental rhinovirus infection. J. Am. Med. Assoc. 186: 578.

23. Cate, T. R., R. B. Couch, and K. M. Johnson. 1964. Studies with rhinoviruses in volunteers: production of illness, effect of naturally acquired antibody, and demonstration of a protective effect not associated with serum antibody. J. Clin. Invest. 43: 56.

24. Buckland, F. E., M. L. Bynoe, L. Rosen, and D. A. J. Tyrrell. 1961. Inoculation of human volunteers with E.C.H.O. virus type 20. Brit. Med. J. 1: 397.

25. Edmondson, W. P., R. H. Purcell, B. F. Gundelfinger, J. W. P. Love, W. Ludwig, and R. M. Chanock. 1966. Immunization by selective infection with type 4 Adenovirus grown in human diploid tissue culture. II. Specific protective effect against epidemic disease. J. Am. Med. Assoc. 195: 453.

26. Jackson, G. G., H. F. Dowling, and R. L. Muldoon. 1962. Present concepts of the common cold. Am. J. Public Health. 52: 940.

27. Johnson, K. M., H. H. Bloom, B. R. Forsyth, and R. M. Chanock. 1965. Relationship of rhinovirus infection to mild upper respiratory disease. II. Epidemiologic observations in male military trainees. Am. J. Epidemiol. 81: 131.

28. Mufson, M. A., H. H. Bloom, B. R. Forsyth, and R. M. Chanock. 1966. Relationship of rhinovirus in- fection to mild upper respiratory disease. III. Further epidemiologic observations in military personnel. $\mathrm{Am}$. J. Epidemiol. 83: 379.

29. Taylor-Robinson, D., K. M. Johnson, H. H. Bloom, R. H. Parrott, M. A. Mufson, and R. M. Chanock. 1963. Rhinovirus neutralizing antibody responses and their measurement. Am. J. Hyg. 78: 285.

30. Chanock, R. M., J. A. Bell, and R. H. Parrott. Natural history of parainfluenza infection. In Perspectives in Virology. M. Pollard, editor. Burgess Publishing Co., Minneapolis. 2: 126.

31. Smith, C. B., R. H. Purcell, J. A. Bellanti, and R. M. Chanock. 1966. Protective effect of antibody to parainfluenza type 2 virus. New Engl. J. Med. 275: 1145.

32. Cate, T. R., R. D. Rossen, R. G. Douglas, Jr., W. T. Bulter, and R. B. Couch. 1966. The role of nasal secretion and serum antibody in the rhinovirus common cold. Am. J. Epidemiol. 84: 352.

33. Tremonti, L. P., J. S. Lin, and G. G. Jackson. 1967. The role of serum and nasal antibody in parainfluenza type 2 infection. Abstracts from Proceedings of the Seventh Interscience Conference on Antimicrobial Agents and Chemotherapy. 5.

34. Schmidt, N. J., E. H. Lennette, and H. H. Ho. 1966. Observations on antigenic variants of echovirus type 11. Proc. Soc. Exptl. Biol. Med. 123: 696. 